\title{
Mating behavior of ram on ewes at induced estrus during the non-breeding season
}

\author{
Yutaka Fukui, Minoru Tsubaki, Masayuki Kobayashi \\ and Hitoshi Ono \\ Department of Meat Animal Reproduction, Obihiro University of Agriculture \\ and Veterinary Medicine, Obihiro 080
}

\begin{abstract}
Summary. Mating behavior of four Suffolk rams and its effect on fertility in 47 hormonallytreated ewes during the non-breeding season were investigated. Each ram was allowed to mate 11 or 12 ewes in a $5 \times 8 \mathrm{~m}$ breedig pen (single-sire mating). The observation was continuous for $48 \mathrm{hs}$ after hormonal treatment and joining of rams. The items of observation were numbers of mounts and services per ewe, ratio of mounts/services per ram, intervals and distribution order of services in each ram. Mating behavior varied markedly between rams. The mean numbers of mounts and services per ewe were 12.6 and 3.3, 35.7 and 6.6, 8.4 and 1.8, and 36.0 and 2.5 for the four rams (A, B, C, and D, respectively). The ratio of mounts/services (14.6) in the youngest ram (D) was significantly $(P<0.01)$ higher than the ratio of the other three rams. The distribution order of services to estrous ewes by each ram was also variable. Ram mating preference was observed, especially in the youngest ram. However, these differences in ram mating behavior did not relate to detection of estrous ewes. Although the proportions of lambed ewes against the number of marked ewes were not significantly different among the rams used, it was revealed that there was a significant difference $(P<0.05)$ in lambing rates between rams A and D. Maiden ewes had lower $(P<0.025)$ lambing rate $(27.8 \%)$ than parous ewes $(71.4 \%)$. It was considered from the present results that mating behavior of rams and status of ewes (maiden or parous) could be the important factors affecting on fertility during the non-breeding season.
\end{abstract}

(Japan. J. Anim. Reprod., 32, 195-201, 1986)

\section{Introduction}

Fertility of ewes induced into estrus during the non-breeding season is usually lower than in the normal breeding season, because of many factors involved such as methods of hormonal treatment and mating, season, ages of ewe and ram, lactational and nutritional statuses of ewes, and others. Dufour et al. ${ }^{1)}$ and Lunstra \& Christenson ${ }^{2)}$ reported that lowered seminal output and motility and percentage of live spermatozoa between rams within breeds were major factors influencing the reduced fertility of seasonally anestrous ewes. Moreover, selection of rams in a breed with a high quality of semen and possibly a high libido would be the most important factor affecting on fertility for out-of-seasonal breeding ${ }^{3)}$. Differences in mating behavior of rams in different ages and their characteristics would therefore affect directly on fertility in estrus-induced ewes.

The present study was conducted to investigate how mating behavior of four Suffolk rams with different ages affect on fertility of maiden and parous ewes treated with progestogen-pregnant mare's serum gonadotropin (PMSG) during the non-breeding season.

\section{Materials and Methods}

Forty-seven mature Suffolk ewes consisting of 26 maiden (15 months old) and 21 parous 
1986 年 12 月

(3-4 years old) ewes were used for the experiment. All ewes were treated with vaginal sponges containing $60 \mathrm{mg}$ medroxyprogesterone acetate (MAP: The Upjohn International Ltd., Australia) for 9 days followed by an intramuscular injection of 600 IU PMSG (Teikoku-zoki Co. , Japan) two days before sponge removal. After sponge removal, the ewes were randomly divided into four sub-groups for natural mating by four Suffolk rams (ram A: 4 years old, ram B: 3 years old, ram C: 2 years old, and ram D: 15 months old) fitted with 'Sire-Sine' harnesses and crayons. A 'single-sire' mating was performed, as each ram and 11 or 12 ewes were kept into a $5 \times 8 \mathrm{~m}$ breeding pen. Ram mating behavior was observed continuously for $48 \mathrm{hrs}$ after joining.

The following items were recorded; numbers of mounts and services of each ewe, ratio of mounts/services for each ram, intervals and distribution order of services by the rams. Fertility was expressed by lambing rate, and prolificacy was also recorded.

Data of mating behavior and prolificacy were analyzed by the Student's $t$-test, and the chi-sqaure test was used to compare lambing rates.

\section{Results}

\section{Estrus incidence and fertility}

As shown in Table 1, 38 out of 47 ewes $(80.9 \%)$ were marked by rams within $48 \mathrm{hrs}$ after treatment. Of those, 6 ewes were not served at all. Therefore, 32 ewes received more than one service were subjected. The detection of estrous ewes $\left(\chi^{2}=2.52\right.$, d.f. 3$)$ and number of ewes served $\left(\chi^{2}=3.00\right.$, d.f. 3$)$ in each ram were not significantly different. It was found by chi-square test that lambing rate of ewes marked by ram A (75.0\%) was significantly $\left(\chi^{2}=4.23\right.$, d.f. $\left.1: p<0.05\right)$ higher than
家畜繁殖誌 32 巻 4 号

that by ram $\mathrm{D}(27.3 \%)$. Prolificacy was the highest in ram $\mathrm{C}(2.4)$, but this was not significantly different from those of the other rams.

\section{Mating behavior}

The results of mating behavior of each ram are shown in Table 2. The total number of mounts were extremely high in rams $\mathrm{B}$ and $\mathrm{D}$, and numbes of mounts per ewe in both rams $B$ and $\mathrm{D}$ were significantly $(P<0.01)$ higher than that of ram $C$. The number of services per ewe was also significantly $(P<0.01)$ different between rams $\mathrm{B}$ and $\mathrm{C}$. The ratio of mounts/ services was the highest in ram D (14.6), which was significantly $(P<0.01)$ different from those of the other three rams. There was also a significant difference $(P<0.05)$ in the ratio between rams $\mathrm{A}$ and $\mathrm{B}$. The intervals of services in ram B was significantly $(P<0.01)$ shorther than those of the other three rams.

The results of number of services and their distribution order on lambing rate and prolificacy are shown separately for each ram in Table 3. The number of services per ewe was varied in each ram, and did not likely relate to fertility. Ram B served 66 times in 10 ewes (mean 6.6), but only 3 ewes lambed. The service order to estrous ewes was also quite different among the rams. For example, ram $B$ gave 2 to 5 successive services to each of some ewes (R 50, G 13, G 03 and N 157), and on the other hand, ram $\mathrm{C}$ served different ewes in order (B 127, G 28 and N 156). It was observed that the youngest ram $D$ preferably served to a certain parous ewe (B 149) throughout the estrous period.

\section{Maiden and parous ewes}

The results of number of services per ewe and fertility in maiden and parous ewes mated by the four different rams are shown in Table 
Table 1. Results of estrus incidence, fertility and prolificacy in ewes served by different rams during the non-breeding season

\begin{tabular}{lccccc}
\hline \multirow{2}{*}{ Items } & \multicolumn{3}{c}{ Rams } & Total \\
\cline { 2 - 5 } & $\mathrm{A}$ & $\mathrm{B}$ & $\mathrm{C}$ & $\mathrm{D}$ & \\
\hline No. ewes treated $^{* 1}$ & 12 & 12 & 11 & 12 & 47 \\
No. ewes marked $^{* 1}$ & 8 & 10 & 9 & 11 & 38 \\
No. ewes served $^{* 1}$ & 7 & 10 & 6 & 9 & 32 \\
No. ewes lambed $^{*}$ & 6 & 3 & 3 & 3 & 15 \\
Lambing rate (\%) $^{* 2}$ & $75.0^{\mathrm{a}}$ & $30.0^{\mathrm{a}, \mathrm{b}}$ & $33.3^{\mathrm{a}, \mathrm{b}}$ & $27.3^{\mathrm{b}}$ & 39.5 \\
Prolificacy & $1.3^{\mathrm{a}}$ & $1.3^{\mathrm{a}}$ & $2.4^{\mathrm{a}}$ & $1.0^{\mathrm{a}}$ & 1.5 \\
& \pm 0.8 & \pm 0.6 & \pm 0.9 & \pm 0.0 & \pm 0.6 \\
\hline
\end{tabular}

*1 Within $48 \mathrm{~h}$ after treatment.

*2 Against the number of ewes marked.

a.b The figures with the different superscripts in each item are significantly different $(P<0.05)$.

Table 2. Characteristics of mating behavior in the rams

\begin{tabular}{lcccc}
\hline \hline \multirow{2}{*}{ Items } & \multicolumn{4}{c}{ Rams } \\
\cline { 2 - 5 } & $\mathrm{A}$ & $\mathrm{B}$ & $\mathrm{C}$ & $\mathrm{D}$ \\
\hline No. ewes in estrus & 8 & 10 & 9 & 11 \\
No. mounts observed & 101 & 357 & 76 & 396 \\
No. mounts per ewe & 12.6 & $35.7^{\mathrm{a}}$ & $8.4^{\mathrm{b}}$ & $36.0^{\mathrm{a}}$ \\
$\quad$ (mean \pm sD) & \pm 9.1 & \pm 21.3 & \pm 2.5 & \pm 22.1 \\
No. services observed & 26 & 66 & 66 & 27 \\
No. services per ewe & 3.3 & $6.6^{\mathrm{a}}$ & $1.8^{\mathrm{b}}$ & 2.5 \\
$\quad$ (mean \pm sD) & \pm 3.4 & \pm 4.3 & \pm 1.7 & \pm 3.6 \\
Ratio of mounts/services & $3.5^{\mathrm{b}}$ & $5.4^{\mathrm{c}}$ & $4.7^{\mathrm{b}, \mathrm{c}}$ & $14.6^{\mathrm{a}}$ \\
Interval of services & $60.2^{\mathrm{a}}$ & $32.6^{\mathrm{b}}$ & $105.4^{\mathrm{a}}$ & $75.4^{\mathrm{a}}$ \\
$\quad$ (mean \pm sD: minutes) & \pm 55.6 & \pm 23.6 & \pm 82.0 & \pm 63.0 \\
\hline
\end{tabular}

a,b,c The different superscripts show significant differences in each item; a v. $\mathrm{b}$ and a v. c: $P<0.01, \mathrm{~b}$ v. c: $P<$ 0.05 .

Table 3. Effects of number of services and the order per ewe by the different rams on fertility and prolificacy

1) $\operatorname{Ram} A$

\begin{tabular}{ccclrcr}
\hline \hline Ear tag & Ewes $^{\mathrm{a}}$ & $\begin{array}{c}\text { Time of } \\
\text { estrus }(\mathrm{h})^{\mathrm{b}}\end{array}$ & \multicolumn{1}{c}{ Order of services } & $\begin{array}{c}\text { No. of } \\
\text { services }\end{array}$ & Lambing & $\begin{array}{c}\text { No. of } \\
\text { lambs born }\end{array}$ \\
\hline R 59 & P & 24 & $1,5,7,10,13,18$ & 6 & Yes & 1 \\
B 109 & P & 24 & $2,3,4,8,9,11,12,15,17,19$ & 10 & Yes & 1 \\
G 14 & M & 24 & 6 & 1 & Yes & 1 \\
G 92 & M & 24 & 20 & 1 & No & - \\
G 93 & M & 24 & 25 & 1 & Yes & 1 \\
G 75 & M & 32 & $14,23,26$ & 3 & Yes & 3 \\
R 42 & P & 32 & $16,21,22,24$ & 4 & Yes & 1 \\
\hline
\end{tabular}

${ }^{a} \mathrm{P}$; parous, $\mathrm{M}$; maiden.

b After treatment. 
2) Ram B

\begin{tabular}{|c|c|c|c|c|c|c|}
\hline Ear tag & Ewes & $\begin{array}{l}\text { Time of } \\
\text { estrus (h) }\end{array}$ & Order of services & $\begin{array}{c}\text { No. of } \\
\text { services }\end{array}$ & Lambing & $\begin{array}{c}\text { No. of } \\
\text { lambs born }\end{array}$ \\
\hline $\mathrm{R} 50$ & $\mathrm{P}$ & 16 & $1,2,3,4,5,9,13,21,22,24,26,33,41$ & 13 & Yes & 2 \\
\hline G 13 & M & 16 & $6,7,8,10,11,18,20,23$ & 8 & No & - \\
\hline N 148 & $\mathrm{P}$ & 16 & 16 & 1 & No & - \\
\hline G 79 & M & 20 & $12,14,15,17,19,25,27,30$ & 8 & Yes & 1 \\
\hline G 23 & M & 28 & $28,34,40,49,63,65$ & 6 & No & - \\
\hline G 03 & M & 28 & $29,32,37,44,47,48,52,55,58,59,64$ & 11 & No & - \\
\hline G 20 & M & 28 & $31,36,42,51$ & 4 & No & - \\
\hline N 157 & $\mathrm{P}$ & 32 & $35,38,43,46,50,53,54,56,61,62,66$ & 11 & No & - \\
\hline B 95 & $\mathrm{P}$ & 32 & $39,45,60$ & 3 & Yes & 1 \\
\hline G 41 & M & 36 & 57 & 1 & No & - \\
\hline
\end{tabular}

3) Ram C

\begin{tabular}{ccclccc}
\hline \hline Ear tag & Ewes & $\begin{array}{c}\text { Time of } \\
\text { estrus (h) }\end{array}$ & \multicolumn{1}{c}{ Order of services } & $\begin{array}{c}\text { No. of } \\
\text { services }\end{array}$ & Lambing $\begin{array}{c}\text { No. of } \\
\text { lambs born }\end{array}$ \\
\hline B 127 & P & 16 & $1,3,6$ & 3 & No & - \\
G 28 & M & 16 & 2,4 & 2 & Yes & 2 \\
N 156 & P & 20 & 5,10 & 2 & Yes & 3 \\
G 74 & M & 28 & $7,8,9,11,14$ & 5 & No & - \\
G 10 & M & 36 & $12,13,15$ & 3 & No & - \\
R 34 & P & 40 & 16 & 1 & Yes & 3 \\
\hline
\end{tabular}

4) Ram D

\begin{tabular}{|c|c|c|c|c|c|c|}
\hline Ear tag & Ewes & $\begin{array}{l}\text { Time of } \\
\text { estrus (h) }\end{array}$ & Order of services & $\begin{array}{c}\text { No. of } \\
\text { services }\end{array}$ & Lambing & $\begin{array}{c}\text { No. of } \\
\text { lambs born }\end{array}$ \\
\hline G 44 & M & 4 & 1,9 & 2 & No & - \\
\hline B 149 & $\mathrm{P}$ & 4 & $3,5,6,7,10,11,12,15,18,19,20,21,23$ & 13 & Yes & 1 \\
\hline G 08 & M & 16 & 2 & 1 & No & - \\
\hline G 24 & M & 16 & 4 & 1 & No & - \\
\hline G 66 & M & 20 & 13,16 & 2 & No & - \\
\hline $\mathrm{R} 26$ & $\mathrm{P}$ & 24 & 8,26 & 2 & No & - \\
\hline N 52 & $\mathrm{P}$ & 24 & 14,25 & 2 & Yes & 1 \\
\hline G 81 & M & 24 & 27 & 1 & No & - \\
\hline $\mathrm{R} 60$ & $\mathrm{P}$ & 28 & $17,22,24$ & 3 & Yes & 1 \\
\hline
\end{tabular}

4. The proportion of lambed ewes was significantly $(P<0.025)$ lower in the maiden ewes $27.8 \%$ ) than in the parous ewes $(71.4 \%)$. No maiden ewes served by ram $\mathrm{D}$ lambed. The mean number of services per maiden (3.4 \pm 3.0$)$ and parous $(5.3 \pm 4.5)$ ewes were not significantly different. There was a significant difference $(P<0.01)$ in the number of services per maiden ewes among the rams, but not in the parous ewes. Rams A and D served less to the maiden ewes than the parous ewes as compared with those of the other rams.

\section{Discussion}

The characteristics of mating behavior were markedly different among the four rams in the present study.

However, ram mating behavior such as 
Table 4. Fertility and number of services in maiden and parous ewes served by the four different rams

\begin{tabular}{cccccc}
\hline \hline \multirow{2}{*}{ Items } & \multicolumn{3}{c}{ Rams } & \multirow{2}{*}{$\begin{array}{c}\text { Total } \\
(\%)\end{array}$} \\
\cline { 2 - 5 } & $\mathrm{A}$ & $\mathrm{B}$ & $\mathrm{C}$ & $\mathrm{D}$ & \\
\hline $\begin{array}{c}\text { No. ewes lambed/served } \\
\text { Maiden }\end{array}$ & $3 / 4$ & $1 / 6$ & $1 / 3$ & $0 / 5$ & $5 / 18$ \\
Parous & $3 / 3$ & $2 / 4$ & $2 / 3$ & $3 / 4$ & $(27.8)^{*}$ \\
& & & & $(71.4)^{*}$ \\
No. services per ewe & & & & \\
(mean \pm sD) & $1.5^{\mathrm{a}}$ & $6.3^{\mathrm{a} . \mathrm{b}}$ & $3.3^{\mathrm{c}}$ & $1.4^{\mathrm{b} . \mathrm{c}}$ & 3.4 \\
Maiden & \pm 1.0 & \pm 3.5 & \pm 1.5 & \pm 0.5 & \pm 3.0 \\
Parous & 6.7 & 7.0 & 2.0 & 5.0 & 5.0 \\
& \pm 3.1 & \pm 5.9 & \pm 1.0 & \pm 5.4 & \pm 4.5 \\
\hline
\end{tabular}

${ }^{*} P<0.025$.

The same superscripts indicate significant differences (a, b: $P<0.01, \mathrm{c}: P<0.05$ ).

number of services and their service order for each ewe did not affect on fertility, except between rams $\mathrm{A}$ and $\mathrm{D}$, in hormonally treted ewes during the non-breeding season. This is in agreement with the results of Hulet et al. ${ }^{4)}$, Mickelson et al. ${ }^{5)}$ and Rosciszewska ${ }^{6)}$. It seems that the quality of semen of the rams in the present study was never low enough to affect the fertility. Ram A with the lowest ratio of mounts/services resulted in the highest fertility, which might relate to a significant difference from the lambing rate of ram $\mathrm{D}$. The low fertility of ewes served by ram B was likely due to dilution of semen with the increase of services. A higher number of services per ewe was not necessarily related to a high fertility. As in rams $\mathrm{A}$ and $\mathrm{C}$, one to 3 services by rams with a high quality of semen would be enough to conceive ewes.

Little informations are available in the distribution order of services on fertility of estrus-induced ewes during the non-breeding season. Tomkins \& BRYANT ${ }^{7)}$ suggested that to achieve maximum fertility it will be desirable for the first 20 to 30 ejaculates to be evenly distributed among the synchronized ewes in the flock mating. In the present study, the total ejaculates of each ram were less than 30 except ram B. GiBson \& JEWELL ${ }^{8)}$ reported that the decline in sperm number resulting from frequent services affected the fertility of the low semen quality rams more severely than that of the high quality rams. From these respects, it would be the most important to select rams with the high quality of semen espeacially for out-of-seasonal breeding. As an alternative mean, hand mating could be useful to obtain the maximum fertility if used the rams with a high quality of semen for the small-farming system.

It was interesting to note that the youngest ram D showed a typical 'ram preference' to a certain parous ewes. TIlbrook et al. ${ }^{9)}$ indicated that estrous ewes had an individual 'attractiveness' to rams and the uneven distribution of spermatozoa amongst ewes affected on fertility in the flock mating. In the present study, ram D devoted almost half of his services to the ewe. This ram was the youngest and sexually the most active among the rams used in the present study. The phenomenon was likely caused by not only 'ram preference' 
but also an individual 'attractiveness' of the ewe. Tilbrook et al. ${ }^{9)}$ reproted that 'attractiveness' to rams was a relatively stable phenomenon and the behavior of the ewes did not affect their 'attractiveness'. On the other hand, the number of services is not simply the results of 'ram preference' to estrous ewes, but involves ewe initiative, especially to young ram as shown in the present study. Sexual behavior in ewes is quite different with thier ages. Parous-aged ewes display a great deal of interest in the rams ('ram-seeking ability') ${ }^{10)}$, but maiden-young ewes wandered away from rams during courting and after mating ${ }^{11}$. Also, the shorter length of estrous period in maiden ewes ${ }^{12)}$ influences on the number of services and the subsequent fertility. In the present study, numbers of services per maiden ewe were significantly variable among the rams, but not in the parous ewes, which affected on the fertility. It was considered that one of the major reasons for the lowered fertility of maiden ewes was impaired sperm transport combined with low mucus production in the female reproductive tract, as compared with aged ewes ${ }^{13,14}$.

It was also found in the present study that the ewes marked by rams were not always served. On this respect, hand mating has an advantage over the flock or natural mating as EJACULATES can be observed. It was difficult to predict fertility by the numbers of mounts and services per ewe, and the degree of crayon marks. It was therefore considered that important factors affecting on fertility of estrus-induced ewes during the non-breeding season would be mating behavior of rams $^{1,2)}$ and status of ewes (maiden or parous) ${ }^{15)}$.
Station, Hokkaido, Japan for the use of animals and facilities, Dr. S. H. Langford, The Upjohn International Ltd. , Australia and Teikoku-zoki Co. , Japan for the supply of MAP vaginal sponges and PMSG, respectively. The authors also wish to thank Dr. J. F. Hurnik, University of Guelph, Canada for variable discussion and comments on this study during his stay in Japan.

\section{References}

1) Dufour JJ, MH Fahmy \& F Minvielle: $J$. Anim. Sci. , 58, 416, 1984.

2) Lunstra DD \& RK Christenson: J. Anim. Sci., 53, 448, 1981.

3) Fukui Y, M Kobay ashi \& H Ono: Jpn. J. Anim. Reprod., 31, 16, 1985.

4) Hulet CV, Rl Blackwell, SK Encanbrack, DA Price \& LO Wilson: J. Anim. Sci., 21, 870, 1962.

5) Mickelson WD, LG Paisley \& JJ Dahmen: Theriogenology, 18, 79, 1982.

6) Rosciszewska ZE: Anim. Reprod. Sci., 7, 517, 1984.

7) Tomkins T \& MJ Bryant: Anim. Prod., 22, 371, 1976.

8) Gibson RM \& PA Jewell: Behaviour, 80, 9, 1980.

9) Tilbrook AJ, Al Synnot, WJ Fulkerson \& Dr Lindsay: Proc. Seminar on Reproduction in Farm Animals (Oldham CM, AM Paterson \& DT Pearce eds.), Aust. Soc. Anim. Prod., W. A. Branch, pp. 95, 1983.

10) Lindsay DR \& IC Fletcher: Anim. Behavir., 20, 452, 1972.

11) Gonyou HW: Appl. Anim. Ethol., 11, 341, 1984.

12) Salamon S: Artificial Insemination of Sheep (Salamons ed.), Sydney University Press, pp: 22, 1976.

13) Kennedy TG: Ph. D. Thesis, The University of New South Wales, Australia, 1969.

14) Selaive-Villarroel AB \& JP Kennedy: Theriogenology, 20, 543, 1983.

15) Fukui $Y, M$ Kobayashi, M Kojima \& H Ono: Theriogenology, 24, 631, 1985.

(Received May 11, 1986)

Acknowledgements

We wish to thank the staff at the Tawa Field 


\title{
非繁殖季節に発情を誘起された雌羊の受胎におよぼす雄羊の性行動
}

\author{
福井豊・椿実・小林正之・小野斉
}

(帯広畜産大学畜産学部肉畜増殖学教室)

47 頭のサフォーク種雌羊について, 非繁殖季節に 60 mg の 6-methyl-17-acetoxyprogesterone (MAP) を 含む腔内スポンジと $600 \mathrm{IU}$ 妊馬血清性性腺刺激ホルモ ン (PMSG) で発情誘起した場合の受胎におよぼす雄羊 （4頭）の性行動の影響について検討した。処理後 11 ま たは 12 頭の雌羊に対して雄羊 1 頭を同居させ，48 時 間連続観察を行った。観察項目は発情雌羊頭数, 発情雌 羊 1 頭当りの雄羊の乗駕回数, 射精回数, 雄羊別の平均 射精間隔 (時間), 乗駕回数/射精回数 (比率), 射精順序 である。

雄羊の性行動は雌羊により有意に変動した。雄羊 4 頭（A：4才，B：3才，C：2才，D：15 加齢）の平 均乗駕回数および射精回数はそれぞれ 12.6 と 3.3 回,
35.7 と 6.6 回, 8.4 と 1.8 回, そして 36.0 と 2.5 回で あった。乗駕回数/射精回数については、最も若齢の雄 羊（D） が 14.6 と他の 3 頭のそれよりも有意に（P< 0.01）高かった。雌羊に対する雄羊の射精順序も雄羊の 個体により異なり, 雄羊 D はある特定の雌羊に集中し て射精した。このような雄羊の性行動は雌羊の発情出現 率に有意な差を示さなかった。しかし，雄羊 A と雄羊 $\mathrm{D}$ の受胎率に有意な $(\mathrm{P}<0.05)$ 差が見られた（75.0\%

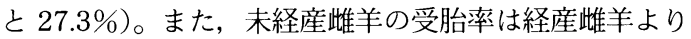
あ有意に（P<0.025）低かった（27.8\%と $71.4 \%) 。$

以上の結果から, 非繁殖季節に発情誘起された雌羊 について自然交配を行う場合, 雄羊の性行動および雌羊 の経産の有無を考慮に入れる必要があると考えられた。 